\title{
認知症との共生の鍵となる取り組みの最前線
}

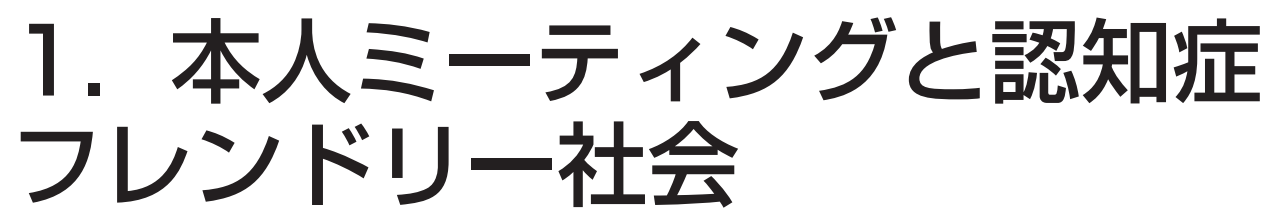

The dementia meeting held by persons living dementia and dementia friendly society

\section{徳田 雄人}

\section{要 約}

医療福祉分野に限らず, 生活を支える産業や地域組織が認知症の人に対応していく必要があるという考え 方が広まりつつある. 認知症の人にとつての使いやすさや利用のしやすさは, 認知症当事者の経験から導き だされるものであり, 本人ミーティングを初めとして, 当事者の声を集め, 新たな地域や社会を作るために 翻訳し，役立てていく仕掛けが求められている.

Key words 認知症フレンドリー社会, 認知症フレンドリーコミュニティ, 本人ミーティング, 地域共生社会

（日老医誌 $2020 ； 57 ： 17-21$ )

\section{認知症フレンドリー社会とは}

認知症の人の行方不明，交通事故，詐欺被害や家族 や後見人による横領，接客業における認知症の人との トラブルなど，近年，認知症のことが毎日のように ニュースとなっている，認知症の人が増加する中，医 療や福祉以外の分野でも，認知症の人とどのように接 して行くかが大きな課題になりつつある. そうした中, 国際的に注目を集めるキーワードのひとつが，認知症 フレンドリー社会である。認知症フレンドリー社会と は, 認知症の人にとって使いやすい, 認知症の人の視 点にたった設計がされた社会のことである．従来の医 療を中心とした従来の考え方では, 病気が問題を引き 起こすので，予防や治療で問題を減らそうというアプ ローチだったのに対し，認知症フレンドリー社会の考 え方では，認知症に関係する出来事を，認知症に伴う
症状を持つ人々と周囲の環境との間で起こる現象とと らえ, 病気ではなく, 地域や社会の側を変えていこう というアプローチである。例えば，お金にまつわるこ とで考えると，これまで，金融機関の有人空口でお金 を引き出していた方が, 複雑な仕様の ATMになっ たことで引き出しが難しくなり，在宅生活が継続でき なくなったという事象は, 病気の進行というよりは, 社会の側の変化に原因があると考え, 高齢者や認知症 の人にもお金の引き出しや管理がしやすい方法を考え ていこうということになる。国家戦略として認知症フ レンドリー社会を推進する英国では, 業種別に委員会 が設けられ，生活を支える様々なセクターで認知症フ レンドリーになるための事例や知見が蓄積されつつあ る.

特定非営利活動法人認知症フレンドシップクラブ理事

連絡責任者：徳田雄人 NPO 法人認知症フレンドシップクラブ〔テ184-0002 東京都小金井市梶野町 1-2-36 PO-TO N-01〕 e-mail: tokuda.takehito@dfc.or.jp

doi: $10.3143 /$ geriatrics.57.17 


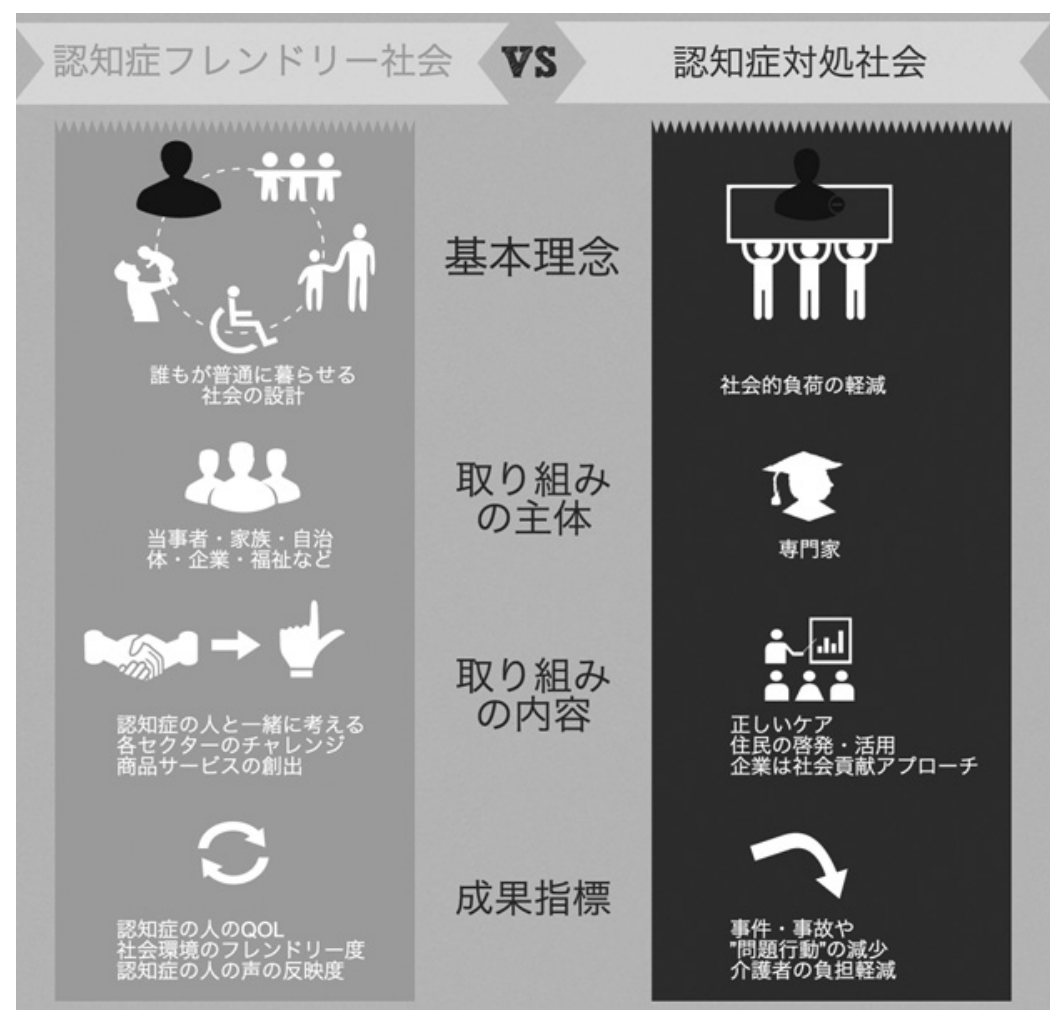

出典：著者作成

図 1 認知症フレンドリー社会と認知症対処社会

\section{認知症フレンドリー社会と認知症対処 社会}

認知症フレンドリー社会は，これまでの認知症の課 題に対するアプローチと比較するとより性格が明確に なる．図 1 は，筆者が従来のアプローチを認知症対処 社会として，両者を整理したものである.

認知症対処社会では, 認知症の人自身が症状として 問題を引き起こしていると考えているため，認知症の 人が増加することは，すなわち問題を多く生み，社会 的負荷が増大寸るので，それに対処しなくてはいけな いという考え方が基盤にある，取り組みの主体は，対 処のプロとしての医療やケアの専門家であり，介護家 族や地域住民には正しい情報を伝え，啓発しょうとい う発想になる。一般企業の取り組みは，こうした問題 とは直接関わりがないので, 地域の取り組みに寄付を したりする，社会貢献が中心となる，成果としては， 事件や事故，問題とされる行動の削減などを持って測
られることになる。これに対して, 認知症フレンドリー 社会では, 認知症の課題を, 認知症の人が持つ症状と 周囲の環境との間で起こる現象ととらえるので, 取り 組みの主体や成果指標が大きく変わってくる，認知症 の人の暮らしづらさの多くは，生活をとりまくインフ ラや空間デザイン，機械のインターフェイスなどに起 因しており，これらを改善することで, 課題解決が(少 なくとも一部は）できるということなる.

2014 年に実施した認知症の人へのアンケート調查 では，認知症の人が，認知症となることで，外出や交 流の機会を減らしていることが分かった（図 2).

電車, 買い物, 外食に行く機会が減った人は 6 割〜 7 割，また友人知人と会う機会も減った人も 7 割だっ た，社会生活を送る上で，外に出かけ，誰かに会うと いう行為は必要な行為であるが，多くの人がそれらを 減らしている害態が分かった，その理由について尋称 た設問への回答からは，症状そのものを理由にあげた 人もいたが，環境面での回答をする人が 4 割〜 5 割に 


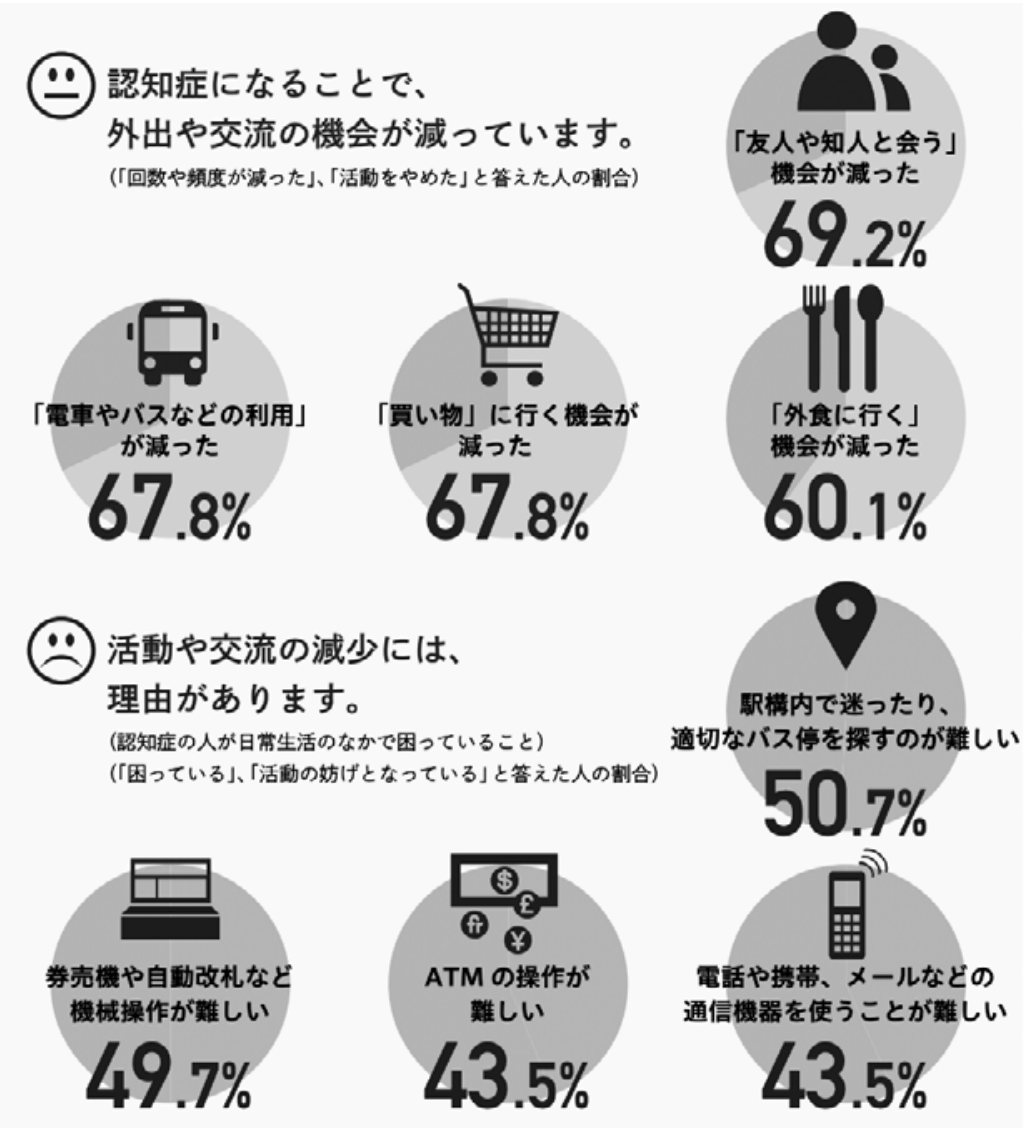

図 2 認知症の人の外出・交流の機会の減少と要因

出典：国際大学グローバル・コミュニケーション・センター

「認知症の人にやさしいまちづくりガイド」(平成 26 年度 厚生労働省 老人保健健康増進等事業 認知症の人にやさしいまちづくりの推進に関する調查研究事業)

のぼった．例えば,「駅構内で迷ったり，適切なバス停 を探すのが難しい」,「券売機や自動改札などの機械操 作が難しい」,「ATMの操作が難しい」といったもの である，症状そのものによる困りごともさることなが ら，環境面での理由で，社会生活を送ることが難しく なっていることが浮き彫りになった。このことは，逆 に言えば，こうした環境面での課題を解決すれば，4 割〜 5 割の人の外出や交流の機会を減らさずに済む可 能性があることを示している.

図 1 で示した認知症対処社会は, 一見, 社会課題に 対する一般的なアプローチのようにも見えるが，顕在 化した事故や事件に引きずられて，短期的な対処を繰 り返すと, 誰もが望まない状況を生み出す可能性もあ
る. 昨今, 話題となることが多い認知症の人の行方不 明の課題を例にとり考えてみたい. 認知症の人が行方 不明となる件数は, 近年増加傾向にあり, 1 万 7 千人 （2018）となっている．多くは，警察に届け出がされ た後, 所在が見つかっているが, およそ 5 百人亡くなっ ている。事件や事故が起こると社会や地域の関心も集 まるため，介護施設などでは，外出を控えたり，部屋 に施錠をして，利用者が自由に移動できないような管 理を行うところも出てきている. 2007 年に爱知県大 府市で認知症の人が鉄道事故で亡くなった事故では, 家族の管理責任が裁判でも争点となり, 介護家族など の間にも管理責任を問われる危惧から，認知症の人の 外出や交流を抑制する傾向も出始めている. 短期的な 


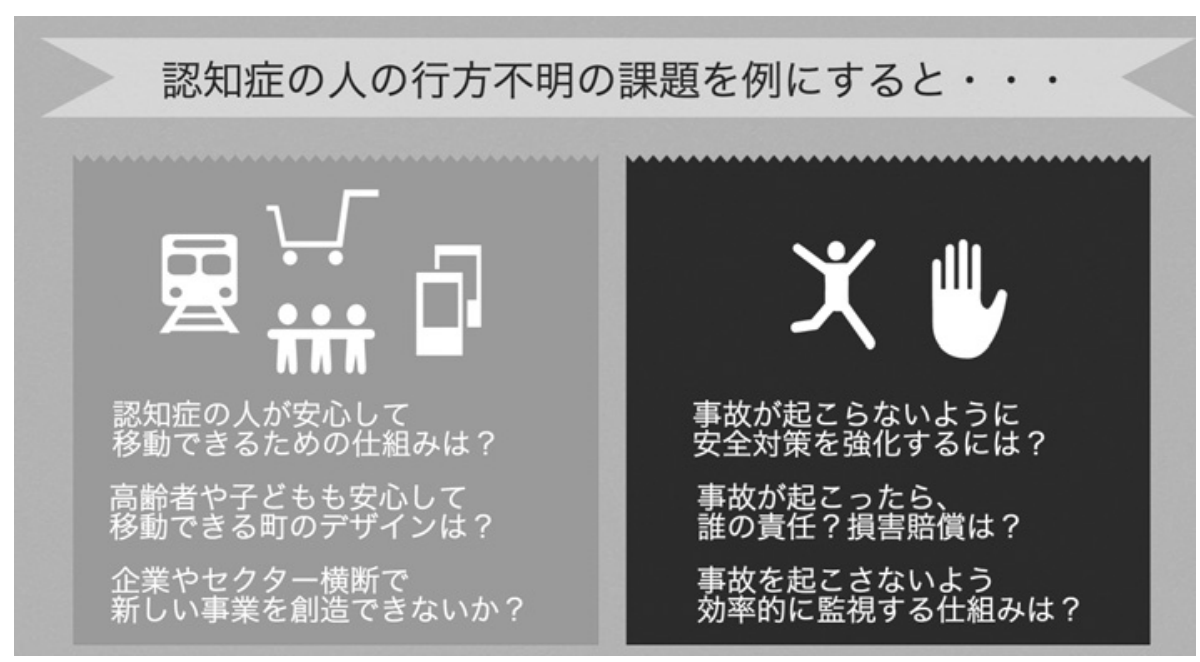

出典：著者作成

図 3 認知症の人の行方不明の課題を例にすると

視点から事故を減らすということだけを考えれば，認 知症の人が外に出ないような取り組みを強化すれば, 事故は減らすことが可能であるが，認知症の人自身が 閉じ込めらた環境で暮らすことは，本人にとって望ま しくない上に, ADLの低下や行動心理症状を引き起 こし，逆に介護家族の負担を増加させたり，医療ケア の現場においても困難事例につながりやすく，長期的 には望ましくない結果を生み出すことが予想される.

中長期的な視点をとると，図 3 のように，認知症フ レンドリー社会をつくるために, 認知症の人も外出で きる環境面での改善に着目する必要がある。認知症の 人が外出する際に，交通手段，出かけた先の空間，人 的対応などのどこにバリアがあるのかを把握し, 改善 をすることで，全てではないにしろ，一定の割合の人 は, 認知症であっても, 出かけられるような状況を作 ることは可能である. また, こうした改善は, 認知症 に限らず，他の障害を持つ人，子ども，子育て世代な どにとって，共通するものも多く，より広範な人の社 会参加を促進すると考えられる. 認知症の人の直面し ている生活上の課題を起点に, 生活に関連する産業が, 業種やセクターを超えて, 新たな事業を創造すること も可能になる.こうした社会を実現するためには, 個々 の企業や自治体の一部門の取り組みだけでは効果が限 定的であり，業種やセクターを超え，目的を共有する
ソーシャルイノベーションのプロセスが必要である.

\section{本人の経験や声を紡ぎ出す“本人ミー ティング"}

認知症フレンドリー社会を創出するために，第一歩 となるのが, 認知症の人の経験や声を集めることであ る.ここで, 重要になってくるのが, 本稿のもうひと つのキーワードである本人ミーティングである，本人 ミーティングとは,「認知症の本人が集い, 本人同士が 主になって, 自らの体験や希望, 必要としていること を語り合い, 自分たちのこれからのよりよい暮らし, 暮らしやすい地域のあり方を一緒に語り合う場」(長寿 社会開発センター「本人ミーティング開催ガイドブッ ク」)のことである. 平成 28 年度に全国 10 力所で試行 的に実施され, その後, 国が進める認知症施策の中で も，本人ミーティングを全国の自治体で実施していく ことが計画されている，本人ミーティングは，必ずし も決まった形式や方法論がある訳ではなく, 地域や運 営主体によって様々な工夫をしながら実施されている が, 共通してあるのは, 認知症の人や家族は, 診断前 後, 希望をもてるような情報に接する機会も少なく, 社会的に孤立していることが多いため，自然に，自ら の経験や思いを出すことが難しい状況にあるため, 同 
じ経験をした人たちが集まり，安心して語れる場を各 地につくる必要があるという考え方である.

例えば，東京都の町田市で活動している「認知症と ともに歩む・本人会議」は, 地元の NPO が運営して いる場で，週 1 回，お昼を挟んで 4 時間程度，認知症 の人が集まって話をしている.1回に集まるのは，5〜 10 人程度. NPO のメンバーが司会をするが，特別な 議題がある時もあるが，日常のとりとめもない会話が 続くこともある．認知症と診断された前後の人々たち も，こうした場にやってくることで，同じ経験をした 人々の話に勇気をもらい，自らの考えや希望を語るよ うになっていく。こうした話の中から, 時折, それぞ れの認知症の人がどのような暮らしをしているのか, どのような希望を持って暮らしているのかについても 語られる.ここには, 町田市の行政職員がやってくる こともあれば，自社の商品やサービスについて意見を 求めに企業の人がやってくることもある. 町田市は, 認知症フレンドリーコミュニティとして注目される自 治体のひとつであり，認知症の人と協働して作ったま ちづくりのビジョン「まちだアイ・ステートメント」, スターバックスでの認知症カフェ「Dカフェ」, 認知 症の人の働く・社会参加の推進などが知られるが，そ の全ての企画運営に認知症の人が参加している。こう した背景には, 本人会議という場と, 積極的にニーズ や声を伝えたいと思う認知症の人がいることがある. 本人ミーティングという名称を持つかどうかは問わ ず, 認知症フレンドリー社会をつくっていくためには, こうした場がもつ機能を, 強化, 普及させていく必要 がある。

本人の経験と, 社会で求められること のギャップを埋める

本人ミーティングと，その場を起点とした社会環境
の設計や改善という文脈では, まだ大きな課題がある. 例えば，認知症施策を担う自治体担当者や認知症の人 の使いやすい商品サービスを考える担当者が, どのよ うに本人と接点を持ち, どのようなプロセスを経るこ とで, 認知症フレンドリーなソリューションがでるの かという点では，まだ事例の蓄積が少ないのが現状で ある。

2018 年 11 月，筆者も運営に携わる認知症未来共創 ハブというネットワーク組織が立ち上がった。認知症 の人の持つ経験や声を集積し, 自治体や企業などの取 り組みに役立つ形に変換していくためのプラット フォームづくりを目的としている。まだ，取り組みは 始まったばかりであるが, 認知症の人へのインタ ビューを通じて, 認知症の人の経験を整理, 蓄積する 活動や, 認知症フレンドリーコミュニティを目指す地 域との協働などがスタートしている。本人の経験を見 える化し，政策や企業活動の現場で使えるものにいか に翻訳していくかが今後の課題である.

著者の COI（Conflict of Interest）開示：本論文発表内 容に関連して特に申告なし

\section{文献}

1）徳田雄人：認知症フレンドリー社会, 岩波書店, 2018.

2) 国際大学グローバル・コミュニケーション・セン ター：認知症の人にやさしいまちづくりガイド, 2014.

3）長寿社会開発センター：本人ミーティング開催ガイド ブック, 2017.

4） NPO 法人認知症フレンドシップクラブ：みんながつ くる認知症フレンドリーまちだ，2018.

5）認知症未来共創ハブ. https://designing-for-dementia. jp/

6）まちだ D マップ. https://www.dementia-friendly-ma chida.org/ 